\title{
Nasotracheal tube wire support: a safety device in maxillofacial surgery technical note after five years of experience
}

\author{
Fernando Melhem Elias ${ }^{a}$, Fábio Ricardo Loureiro Sato ${ }^{b}$, Flávio Wellington da Silva Ferraz ${ }^{a}$
}

Elias FM, Sato FRL, Ferraz FWS. Nasotracheal tube wire support: a safety device in maxillofacial surgery technical note after five years of experience. Autopsy Case Rep [Internet]. 2014; 4(1): 59-61. http://dx.doi.org/10.4322/acr.2014.009

\section{ABSTRACT}

A well fixed endotracheal tube is essential for safety during general anesthesia. In maxillofacial surgeries, securely fixing a nasotracheal tube in place has always been problematic. The aim of this article is to describe a simple but effective technique to fasten the nasotracheal tube using a wire support that allows a full range of head movement without interference in the surgical field. During the last 5 years, this device was successfully used in almost two hundred patients with very few complications.

Keywords: Surgery, Oral; Anesthesiology; Intubation

\section{INTRODUCTION}

Fixation of the endotracheal tube and assuring airway patency is of vital importance in any general anesthetic procedure. When the surgical field is not near the head and neck, endotracheal tube fixation does not represent a difficult task. However, in oral and maxillofacial surgeries, particularly when an intraoperative approach of the dental occlusion is required, fixation of the endotracheal tube may become a challenge. In such cases, nasotracheal intubation is the method of choice because it ensures airway patency and at

\section{Description of the Technique}

After the induction of anesthesia, tracheal intubation is undertaken through the nose using either a preformed or an armored cuffed tube. Single black cotton $U$-suture thread is stitched through the nasal mucosa and cartilaginous septum, allowing a primary anchorage. After a first loose limiter the same time provides maximum mobility for the patient's head. Nevertheless, injuries to the nasal soft tissues and even unintentional extubation may occur when the nasotracheal tube is not properly fastened. In this note, we describe a technique to fix the nasotracheal tube using a wire support, made with the metallic guide of the tracheal tube, easily available in the operating room. Our team has successfully used this method during the last five years to prevent nasotracheal tube displacement and its hazardous consequences.

\footnotetext{
a Department of Oral and Maxillofacial Surgery, Hospital Universitário, Universidade de São Paulo, São Paulo/SP - Brasil.

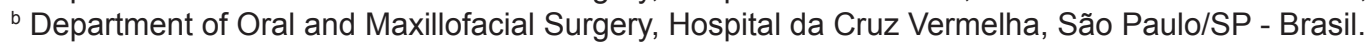

Copyright $\odot 2014$ Autopsy and Case Reports - This is an Open Access article distributed of terms of the Creative Commons Attribution NonCommercial License (http://creativecommons.org/licenses/by-nc/3.0/) which permits unrestricted non-commercial use, distribution, and reproduction in any medium provided article is properly cited. 
tapes are used to fix the turban to the skin of the forehead and posterior neck. This step is of critical importance to avoid displacement of the turban during surgery. Once the turban is properly fastened, a small surgical compress is taped over it, creating a soft cushion to accommodate the intubation wire support, which was previously curved in an M letterform, with U-shaped curves at both extremities (Figure 1).

The next step consists in attaching the wire support onto the compress. The tracheal tube will be tied to the supporting device with the strap that usually comes with the small surgical compress. Both the wire support and compress should be fixed not only to the turban but also to the forehead to avoid any displacement. Afterwards, the turban is curled over the breathing circuit extension connected to the endotracheal tube and fixed by adhesive tape. Finally, the tube extension is fixed to the surgical bed with adhesive tapes, reducing the weight over the wire support and pressure over the patient's occipital region (Figure 2).

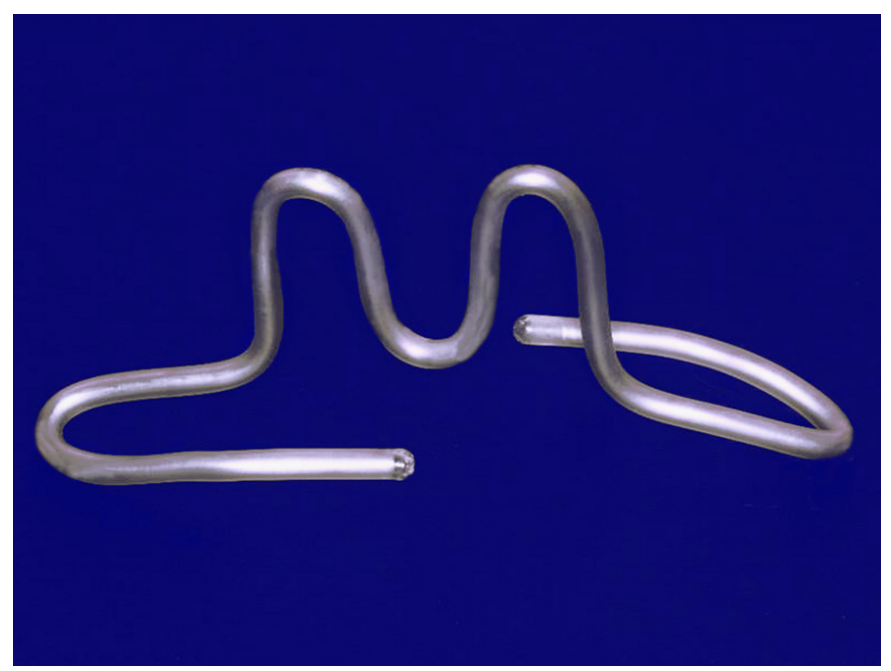

Figure 1 - Wire support bent in the M letter-form, with U-shaped curves at both extremities.
From 2008 to 2013 , this technique was used in 197 patients who underwent general anesthesia for orthognathic, trauma and tumor resection surgeries. For the great majority of patients anesthesia was uneventful. In 10 cases the turban became loose and required reattachment. Six out of these 197 patients experienced slight nasal hyperemia due to the tube pressure. Neither necrosis nor permanent tissue damage was observed. Six patients complained of postoperative occipital pain and two of them had localized alopecia four weeks later, which totally healed afterwards.

\section{DISCUSSION}

The coordinated effort between the surgeon and anesthesiologist is expected during any surgical procedure including extensive maxillofacial surgeries. In this setting the anesthesiologist, apart from taking care of the anesthetic procedures, needs to ensure free movement of the patient's head without kinking the endotracheal tube or accidental extubation. At the same time the surgeon should have full access to the operative field and focused attention without other concerns related to the anesthesia.

Several techniques have been described to maintain the endotracheal tube in place including: the use of adhesive tapes, ${ }^{1}$ ligatures passed around or through the tube,$^{2-4}$ disposable catheter strapping, ${ }^{5}$ suturing the anesthetic tube to the pericranium, ${ }^{6}$ supporting the tube by a Mayo table ${ }^{7}$ and custommade splints. ${ }^{8}$ Adhesive tapes, although simple and non-invasive, have several disadvantages as they may interfere with the operative field, limit the access to the middle and upper thirds of the face and restrict movements of the endotracheal tube. Furthermore, the tapes may become wet or lose
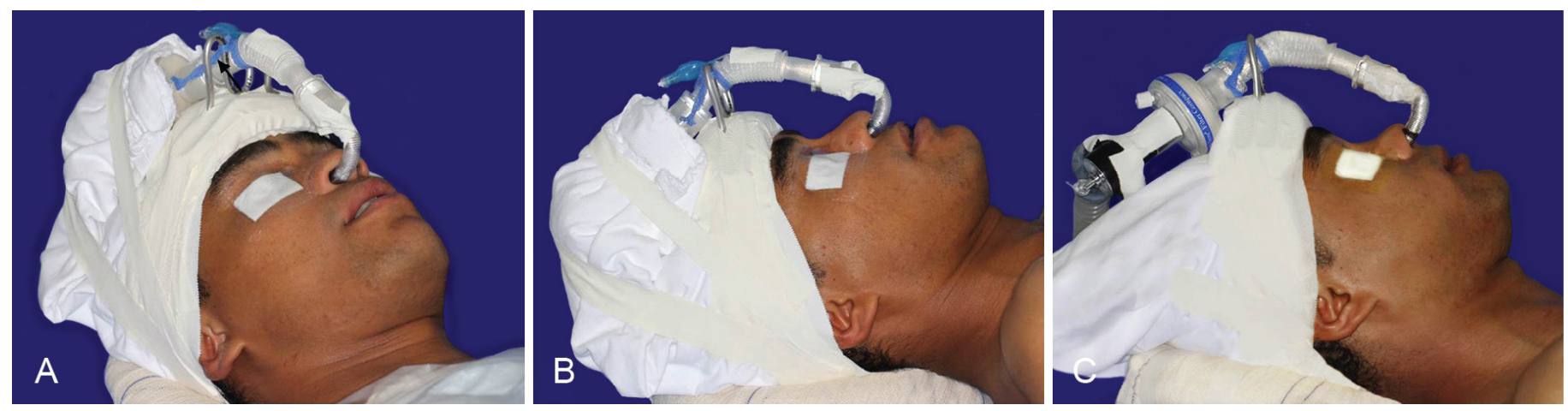

Figure 2 - A - The wire support is taped onto the compress, allowing the tube fixation with a small cord (arrow); B - Nasotracheal tube fixed well away from the operative field, allowing wide range of head movement; C - After bimaxillary orthognathic surgery, neither dislocation of the nasotracheal tube nor damage to the nasal soft tissues were observed. 
adhesiveness in contact with moisture besides triggering allergic reactions. Suturing through the tube presents the risk of puncturing the cuff inflation line causing deflation. This could result in reduced protection of the respiratory tract, loss of the airtight seal necessary for mechanical ventilation and leakage of anesthetic vapors to the environment. Suturing the anesthetic tube to the pericranium may give adequate fixation but does not allow lateral rotation of the tube and could lead to bleeding and infection at the site of the stitch. Custom-made splints restrict the operative field by being placed on the nasal bridge. A common disadvantage of the reviewed methods is the risk of endotracheal tube kinking and compression over the nasal alar cartilage while rotating or tilting the patient's head. These inconveniences are eliminated with the proposed technique described above. However, it is important to remember that this technique is not free of complications and therefore some degree of nasal cartilage injury may occur if the cloth turban loosens up. Another complication is occipital soft tissue injury that may occur due to excessive compression caused by the weight of the breathing extension when it is not properly fixed to the surgical bed. In our series, six patients complained of pain in the occipital region and two of them developed localized alopecia four weeks after the surgery, which healed afterwards. All these patients underwent long lasting orthognathic surgeries. A soft surgical head bolster may decrease the occurrence of such complication. In six cases, mild nasal soft tissue injury was observed coincidently with the laxity of the turban. However, we did not find septal or alar necrosis or unintentional extubation.

\section{CONCLUSIONS}

We found this method of nasotracheal tube fixation effective and safe. It allows a wide range of head movement and seldom interferes with the operative field.

\section{Conflict of interest: None}

Submitted on: $21^{\text {th }}$ September 2013

Accepted on: $22^{\text {th }}$ January 2014
Due to its advantages, including low cost and easy availability in most surgical theaters, it has gained extensive acceptance with oral surgeons and anesthesiologists.

\section{REFERENCES}

1. Fenje N, Steward DJ. A study of tape adhesive strength on endotracheal tubes. Can J Anaesth. 1988;35:198-202. PMid:3356058. http://dx.doi.org/10.1007/BF03010665

2. Wingate G, Stevenson GW, Pensler JM. Rigid endotracheal tube stabilization during craniomaxillofacial surgery. Ann Plast Surg. 1989;23:459-60. PMid:2604335. http://dx.doi.org/10.1097/00000637-198911000-00016

3. Rivera R, Tibballs J. Complications of endotracheal intubation and mechanical ventilation in infants and children. Crit Care Med. 1992;20:93-199. http://dx.doi.org/10.1097/00003246199202000-00008

4. Ota Y, Karakida K, Aoki T, et al. A secure method of nasal endotracheal tube stabilization with suture and rubber tube. J Exp Clin Med. 2001;26:119-22.

5. Donlon WC, Truta MP, Hilt DM. A simple method of nasoendotracheal tube fixation. Ann Plast Surg. 1989;23:4612. PMid:2604336. http://dx.doi.org/10.1097/00000637198911000-00017

6. Altemir FH. Pericranial fixation of the nasotracheal tube. $\mathrm{J}$ Oral Maxillofac Surg. 1986;44:585. http://dx.doi.org/10.1016/ S0278-2391(86)80105-7

7. Baek, RM. Song, YT. A practical method of surgical draping using the performed RAE (Ring-Adair-Elwyn) nasotracheal tube and the mayo table in maxillofacial surgery. Plast Reconstr Surg. 2003;112:1484-5. PMid:14504540. http:// dx.doi.org/10.1097/01.PRS.0000080503.88764.6C

8. Starr DG, Fletcher IR. A new method for securing endotracheal tubes during orthognathic surgery. Br J Oral Maxillofac Surg. 1994;32:260-1. http://dx.doi.org/10.1016/02664356(94)90214-3

Correspondence: Departamento de Cirurgia, Prótese e Traumatologia Maxilofaciais

Faculdade de Odontologia da Universidade de São Paulo

Av. Prof. Lineu Prestes, 2227 - Cidade Universitária - São Paulo/SP - Brazil

CEP: 05508-000 - Phone: +55 (11) 3091-7887

E-mail: fmelias@usp.br 